УДК 616.8

https://doi.org/10.17816/MAJ33848

\title{
POTENTIAL ROLE OF LACTOFERRIN IN EARLY DIAGNOSTICS AND TREATMENT OF PARKINSON DISEASE
}

\author{
A.V. Sokolov', 2,3, I.V. Miliukhina1, Y.P. Belsky, N.V. Belska', V.B. Vasilyev ${ }^{1,2}$ \\ ${ }^{1}$ Institute of Experimental Medicine, Saint Petersburg, Russia; \\ ${ }^{2}$ Saint Petersburg State University, Saint Petersburg, Russia; \\ ${ }^{3}$ The Preclinical Translational Research Centre of the Almazov Centre, Saint Petersburg, Russia
}

For citation: Sokolov AV, Miliukhina IV, Belsky YuP, et al. Potential role of lactoferrin in early diagnostics and treatment of Parkinson disease. Medical Academic Journal. 2020;20(1):37-44. https://doi.org/10.17816/MAJ33848

Received: January 28, 2020

Revised: February 26, 2020

Accepted: March 3, 2020

Incidence of Parkinson disease progressively grows with increasing age and percentage of elderly people in the global population. Clear understanding of the causes of dopaminergic neurons' death in Substantia nigra and Parkinson disease pathogenesis are currently absent, not speaking of an efficient therapy. However, an early diagnosis of dopaminergic neurons' degeneration and prescription of dopamine replacement therapy significantly slow down the rate of symptoms' progression. An increased concentration of iron in Substantia nigra of Parkinson disease patients has been shown in several studies. In this review we summarized the data concerning a potential significance of lactoferrin, the iron-binding protein of exocrine secretions and neutrophils, for early diagnosis and treatment of Parkinson disease. Salivary and lacrimal lactoferrin levels in Parkinson disease patients were higher than those observed in the control group. Plasma levels of lactoferrin inversely correlated with Parkinson disease severity even after treatment with Levodopa, a dopamine agonist, and with monoaminooxidase inhibitors. Lactoferrin levels in cerebrospinal fluid of Parkinson disease patients negatively correlated with the tumor necrosis factor-alpha concentration. Lactoferrin treatment of rodents with several experimental models of Parkinson disease (induced by rotenone, MPTP) protected neurons and mitigated the symptoms of neurodegeneration. Some contradictions about the positive effects of lactoferrin as a remedy in Parkinson disease animal models and possible participation of lactoferrin in accumulation of iron in neurons are discussed.

Keywords: Parkinson's disease; lactoferrin; iron.

\section{ПОТЕНЦИААЬНАЯ РОАЬ ААКТОФЕРРИНА АЛЯ РАННЕЙ АИАГНОСТИКИ И АЕЧЕНИЯ БОАЕЗНИ ПАРКИНСОНА}

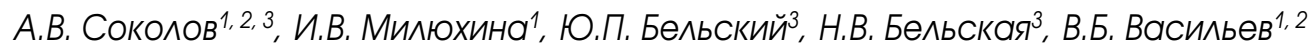 \\ ${ }^{1}$ Федеральное государственное бюджетное научное учреждение «Институт экспериментальной медицины», \\ Санкт-Петербург; \\ ${ }^{2}$ Федеральное государственное бюджетное образовательное учреждение высшего \\ профессионального образования «Санкт-Петербургский государственный университет», Санкт-Петербург; \\ ${ }^{3}$ Федеральное государственное бюджетное учреждение «Научный медицинский исследовательский центр \\ им. В.А. Алмазова» Министерства здравоохранения Российской Федерации, Санкт-Петербург
}

Для цитирования: Соколов А.В., Милюхина И.В., Бельский Ю.П., и др. Потенциальная роль лактоферрина для ранней диагностики и лечения болезни Паркинсона // Медицинский академический журнал. - 2020. - Т. 20. - № 1. - C. 37-44. https://doi. org/10.17816/MAJ33848

Поступила: 28.01.2020

Одобрена: 26.02.2020

Принята: 02.03.2020

Заболеваемость болезнью Паркинсона прогрессивно растет по мере увеличения продолжительности жизни и доли пожилых людей в мировой популяции. В настоящее время не существует эффективных методов терапии, четкого понимания патогенеза болезни Паркинсона и причин гибели дофаминовых нейронов в Substantia nigra. Однако ранняя диагностика дегенерации дофаминовых нейронов и своевременное назначение дофамин-замещающей терапии значительно снижают скорость проявления симптомов заболевания. В ряде исследований было показано, что при болезни Паркинсона в Substantia nigra накапливается железо. В данном обзоре суммированы данные о потенциале использования лактоферрина, железосвязывающего белка экзокринных секретов и нейтрофилов для ранней диагностики и терапии болезни Паркинсона. Концентрация лактоферрина в слюнной и слезной жидкости пациентов с болезнью Паркинсона достоверно выше, чем в контрольных образцах. Концентрация лактоферрина в плазме крови пациентов с болезнью Паркинсона обратно коррелирует с тяжестью симптомов даже после применения леводопы, агонистов дофамина и ингибиторов моноаминооксидазы. Концентрация лактоферрина в спинномозговой жидкости обратно коррелировала с концентрацией фактора некроза опухоли-альфа. Введение лактоферрина грызунам с различными вариантами

List of abbreviations

DA - dopamine; LF - lactoferrin; MPTP - 1-methyl-4-phenyl-1,2,3,6-tetrahydropyridine; PD - Parkinson disease; SN - Substantia nigra; SNpc - Substantia nigra pars compacta. 
экспериментальной болезни Паркинсона (индукция ротеноном, МРТР) защищало нейроны и снижало выраженность клинических проявлений нейродегенерации. В обзоре обсуждены некоторые противоречия между данными о позитивном действии лактоферрина при моделировании болезни Паркинсона у животных и возможности участия лактоферрина в накоплении железа в нейронах.

Ключевые слова: болезнь Паркинсона; лактоферрин; железо.

\section{Introduction}

Parkinson disease (PD) is the major cause of slowly progressive parkinsonism, a clinical syndrome comprising combinations of motor and nonmotor symptoms. The incidence of PD is estimated between 10 and 50 per 100,000 person-years, and its prevalence rate is approximately $0.3 \%$ of the entire population, affecting more than $1 \%$ of individuals above 60 years and up to $4 \%$ of those older than 80 years [1, 2]. The nigrostriatal dopamine (DA) system in aging shares important biological features with PD. Dopaminergic neurodegeneration in PD presents a complex biology of interacting factors. Many of those factors are also present during the aging of DA system. In normal aging a reduced viability of dopaminergic neurons is manifested as impaired function of the system, whereas additional contributions of genetic, environmental, factors are needed to reach the threshold for dopaminergic neurodegeneration in PD [3, 4]. In healthy aging selective accumulation of iron occurs in several brain regions and different cell types, with iron mostly bound to ferritin and neuromelanin. Iron is involved in quite a few cellular processes in the brain. Those include mitochondrial respiration, synthesis of myelin, DNA and neurotransmitters, oxygen transportation, and other components of cellular metabolism. Dysregulation of iron metabolism has been linked to the pathogenesis of several neurodegenerative disorders, including PD, and age-related accumulation of iron might be an important factor that contributes to neurodegenerative processes [5]. Iron has been shown to accumulate in Substantia nigra pars compacta $(\mathrm{SNpc})$ in PD patients. Lees [6] studied micro-architecture of SN in patients with parkinsonism as compared with control cases of varying age. The lateralventral tier of SNpc was identified as selectively vulnerable to the loss of melanized dopaminergic neurons in PD. In patients with PD SNpc was identified as the site of iron accumulation, whereas in controls SN pars reticulata is rich in iron [7-9]. Overlapping of regions detected by iron-sensitive MRI and neuromelanin-sensitive MRI was shown in SN of individuals with PD and healthy controls. The lateral-ventral SNpc was identified as prone to iron accumulation [10].

The clinical application of iron chelators has a bright future in PD therapy [5]. To achieve a better follow-up the earliest possible start of PD treatment is proposed, when movement disorders are not severe $[11,12]$. A number of studies in animal models have shown that lactoferrin (LF), a multifunctional iron-binding glycoprotein, provides neuroprotection against DA neuronal impairment by several mechanisms. Those are not limited to the regulation of iron metabolism, but may involve the inhibition of apoptosis or mitigation of oxidative stress and neuroinflammation [5].

\section{Links between pathogenesis of PD and iron metabolism}

The hypothesis of iron participation in the degeneration of dopaminergic neurons is based on the peculiarities of iron localization in the brain of PD patients. DA, the crucial neurotransmitter involved in PD, easily forms toxic metabolites. Indeed, even in physiological conditions the oxidation of DA by monoamine oxidase results in formation of hydrogen peroxide. Interaction between hydrogen peroxide and iron accumulated in dopaminergic neurons is known as the Fenton reaction producing hydroxyl radicals. These reactive oxygen species provoke oxidative stress featuring the destruction of lipids, proteins, nucleic acids and various antioxidants [13, 14]. Direct oxidative modification of ceruloplasmin with a drop of its ferroxidase activity in cerebrospinal fluid of PD patients is a vivid example of the causative link between the iron deposition in the central nervous system and the oxidative stress. [15]. Elevated level of intracellular iron induced ferroptosis, the programmed cell death associated with accumulation of lipid hydroperoxides produced in the presence of $\mathrm{Fe}(\mathrm{II})$. Moreover, the iron-catalyzed oxidation of DA formed 6-hydroxydopamine. Noteworthy, the latter is used as a neurotoxin to model PD in animals, since it induces iron release from ferritin and the production of reactive oxygen species $[16,17]$.

The pathognomonic sign of familial and sporadic PD is the presence of Lewy bodies. Those contain aggregates of alpha-synuclein, but also are stained in the iron-sensitive histochemical reaction [18]. Alpha-synuclein is mostly contained in presynaptic terminals and may be involved in the compartmentalization, storage, and recycling of neurotransmitters $[19,20]$. The high-affinity iron-binding sites were identified in its structure: D121, N122, and E123 [21]. Experiments with wild-type and mutant form of alpha-synuclein (A30P, A53T, and E46K), 
which is specific for familial cases of PD, showed that $\mathrm{Fe}(\mathrm{III})$ can induce fibrillization of both wild-type and mutant forms of the protein [22]. Under physiological conditions only about $4 \%$ of the soluble monomeric alpha-synuclein is phosphorylated, whereas the protein found in Lewy bodies of PD patients is phosphorylated by more than $90 \%$ [23]. The ${ }^{119}$ DPDNEA(pY)EMPSEEG ${ }^{132}$ phosphopeptide of alpha-synuclein, where Y residue was replaced with phosphotyrosine (pY), possessed a marked selectivity for trivalent metal ions, e.g. $\mathrm{Fe}(\mathrm{III})$, in comparison with the non-modified peptide or the phosphoserine $(\mathrm{pS})$ containing peptide: ${ }^{119}$ DPDNEAYEMP(pS)EEG ${ }^{132}[24,25]$.

5 '-untranslated region of mRNA encoding alpha-synuclein contains the steam-loop structure motif similar to the iron-responsive element of mRNA encoding $\mathrm{H}$ - and L-ferritin, ferroportin, and mitochondrial aconitase [26]. In the absence of iron, iron-regulatory proteins bind the iron-responsive element at the ferritin mRNA and block ferritin translation. In a cellular model with knockdown of iron-regulatory protein 1 , which corresponds to the situation when iron-responsive element do not sense iron, the level of alpha-synuclein mRNA was up-regulated [27]. Depletion of intracellular iron by desferal decreased the level of alpha-synuclein mRNA [28]. This impact of the iron concentration on the regulation of alpha-synuclein synthesis does not seem coincidental if to take into account that both the recombinant protein and lysates of cells with alpha-synuclein overexpression demonstrate the activity of ferric reductase [29]. Overexpression of alpha-synuclein alters the activity of tyrosine hydroxylase, the key enzyme involved in DA synthesis [30].

In 1997 Logroscino and colleagues reported about an alteration of systemic iron metabolism in PD patients [31]. Comparing the latter with a corresponding age group of donors without clinical evidence of PD or other major neurologic or medical disorder revealed a significant decrease of serum iron and the total iron binding capacity, of transferrin and its iron saturation, and of ferritin. Although there was no difference between patients and controls in the overall dietary intake of iron, dietary iron was not related to serum iron. Moreover, there was also no difference between patients with PD who used Levodopa and those who did not, implying that the observed differences in circulating concentrations of iron and iron proteins were not related to dissimilarites in the treatment of PD [31]. The peculiarities of iron metabolism in PD observed in that study were consistent both with previous [32] and subsequent [33] investigations. Importantly, the level of plasma transferrin positively correlated with the severity of tremor in the tremor-dominant PD [34].

\section{Links between lactoferrin and Parkinson disease}

Studies of a connection between LF and the pathogenesis of PD started with an observation of the LF receptor higher content in mesencephalon samples obtained by autopsy from 8 patients with histologically confirmed PD in comparison with 13 individuals with no known history of psychiatric or neurological disorders [35]. This observation immediately placed a theoretical footing for a possible mechanism of pumping iron in the brain of patients with PD [36]. This contradicted the notion that the bacteriostatic activity of LF in exocrine secretions and neutrophils is based on its capacity to sequester iron, otherwise captured by microorganisms. Indeed, LF binds iron about 300 times more avidly than transferrin, but little is known about the regulation of iron release from LF in physiological conditions [37]. Further analysis of cellular distribution in mesencephalon demonstrated the high levels of LF in a large population of neurons in $\mathrm{SN}$ of control cases [38]. Quantitative analysis also demonstrated that patients with PD had higher LF levels in the surviving neurons of $\mathrm{SN}$ as compared with control cases. The authors conclude: "further studies will be necessary to elucidate whether LF acts as an iron scavenger and may represent a protective factor, or conversely, promotes excessive iron accumulation leading to oxidative damage in vulnerable neurons" [38]. In animals the acute administration of 1-methyl-4-phenyl-1,2,3,6-tetrahydropyridine (MPTP) destroys neurons in SN, containing most of the melanin, and causes a PD-like syndrome [39]. Treatment of mice with MPTP caused up-regulation of $L F$ expression accompanied by the synthesis of antioxidant enzymes such as catalase and gamma-glutamyl cysteine synthetase, which may provide the protection of brain tissue from oxidative damage induced by the neurotoxin $[40,41]$. This hypothesis is confirmed by an observation that LF plasma levels inversely correlated with PD severity even after treatment with Levodopa, the DA agonist, and monoaminooxidase inhibitors [42]. Noteworthy, the expression of gamma-glutamyl cysteine synthetase is under control of the nuclear factor erythroid 2-related factor 2, the synthesis of which is induced by LF [43, 44].

Several groups reported about the capacity of both iron-saturated and apo-forms of LF to cross the blood-brain barrier in vitro and in vivo [45-48]. These observations stimulated the studies of LF beneficial effects, when LF-coated nanoparticles were used to deliver drugs and constructions designed for gene therapy in animals with models of PD [49-53]. In parallel several studies demonstrated the anti-anxiety and stress-protective activity of LF mediated via the opioid system and its corticostatic activity [54-57]. 
Pathogenesis of Parkinson disease

Effect

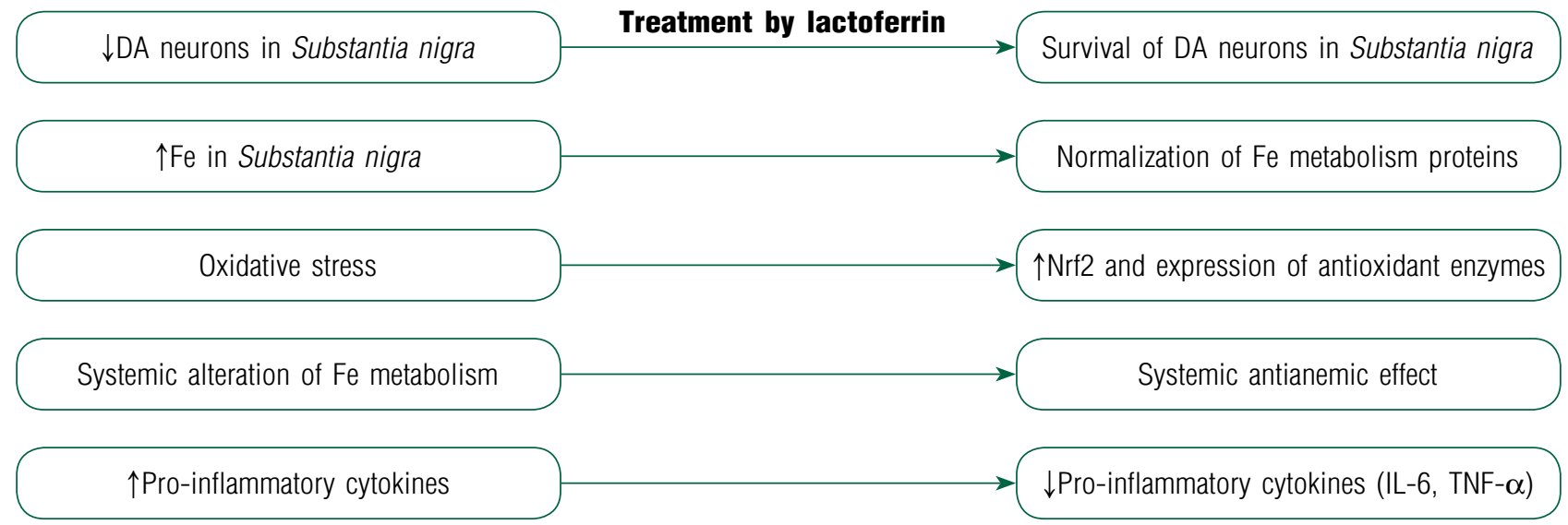

Effects of lactoferrin treatment on the pathogenesis of Parkinson disease modeled in animals: DA - dopamine

Early in this century a peptide hormone hepcidin was discovered. It regulates the iron efflux from cells under inflammatory conditions and iron overload [58, 59]. Iron metabolism is affected by a number of pro-inflammatory cytokines on (e.g. tumor necrosis factor-alpha, interleukin-1beta, interleukin-6) mediated both by iron-regulatory proteins and by hepcidin. This process includes the up-regulation of divalent metal transporter 1 and downregulation of ferroportin, the iron exporter [60]. Antianemic effect of LF is realized by decreasing IL-6, abrogating the endotoxin-mediated degradation of ferroportin and increasing ceruloplasmin ferroxidase activity [61-63]. Ferroxidase activity of ceruloplasmin prevents the ubiquitin-mediated degradation of ferroportin [64]. Participation of LF in iron regulation is also mediated via stabilization of iron-sensitive hypoxia-inducible factors- 1 alpha and -2 alpha $[65,66]$. These transcription factors up-regulate the synthesis of erythropoietin, which demonstrated neuroprotective effects distinct from its antianemic functions [67]. Indeed, intraperitoneal and nasal administration of LF to rodents protects the animals against neurodegeneration, including the rotenone-induced model of PD in rats [42]. These results are confirmed by other studies in which LF protected a culture of dopaminergic neurons from toxic effects of MPTP [67] or mice $[69,70]$ against the MPTP-induced neurodegeneration. In MPTP-treated mice the level of divalent metal transporter 1 in striatum became significantly higher in comparison with the control group, but after LF treatment it was substantially decreased [69]. The following scheme summarizes the effects of LF treatment in PD animal models, differing in the pathogenetic links affected.

The effects of LF and pro-inflammatory cytokines are inverse, which is evidenced by the negative correlation of LF and tumor necrosis factor-alpha levels in cerebrospinal fluid of PD pa- tients [71]. Two recent studies independently suggested a potential usability of LF as non-invasive marker of PD [72, 73]. In fact, the levels of LF in saliva and tears of PD patients were higher than those observed in the control group. Using salivary and lacrimal LF as PD marker seems reasonable, since both fluids are easily obtained as compared with the blood samples and, which is more important, the levels of LF in these exocrine secretions are much higher than the level of oligomeric alpha-synuclein. The latter is widely used for PD diagnosing, but its prevalence in red blood cells, relatively low concentration in biological fluids and contradictory data of meta-analysis diminish its importance as a PD marker $[74,75]$.

Conflict of interest. The authors declare no conflict of interest in financial or any other sphere.

\section{References}

1. de Lau LM, Breteler MM. Epidemiology of Parkinson's disease. Lancet Neurol. 2006;5(6):525-535. https://doi. org/10.1016/S1474-4422(06)70471-9.

2. Elbaz A, Carcaillon L, Kab S, Moisan F. Epidemiology of Parkinson's disease. Revue Neurologique. 2016;172(1):14-26. https://doi.org/10.1016/j.neurol.2015.09.012.

3. Fahn S. Description of Parkinson's disease as a clinical syndrome. Ann NY Acad Sci. 2006;991(1):1-14. https://doi.org/ 10.1111/j.1749-6632.2003.tb07458.x.

4. Larsen JP, Beiske AG, Bekkelund SI, et al. Motor symptoms in Parkinson disease. Tidsskr Nor Laegeforen. 2008;128(18):2068-2071.

5. Jiang $\mathrm{H}$, Song $\mathrm{N}$, Jiao $\mathrm{Q}$, et al. Iron Pathophysiology in Parkinson Diseases. Adv Exp Med Biol. 2019;1173:45-66. https://doi.org/10.1007/978-981-13-9589-5_4.

6. Fearnley JM, Lees AJ. Ageing and Parkinson's disease: substantia nigra regional selectivity. Brain. 1991;114(Pt5):22832301. https://doi.org/10.1093/brain/114.5.2283. 
7. Morris CM, Edwardson JA. Iron histochemistry of the substantia nigra in Parkinson's disease. Neurodegeneration. 1994;3(4):277-282.

8. Sian-Hülsmann J, Mandel S, Youdim MB, Riederer $P$. The relevance of iron in the pathogenesis of Parkinson's disease. J Neurochem. 2011;118(6):939-957. https://doi. org/10.1111/j.1471-4159.2010.07132.x.

9. Wypijewska A, Galazka-Friedman J, Bauminger ER, et al. Iron and reactive oxygen species activity in parkinsonian Substantia nigra. Parkinsonism Relat Disord. 2010;16(5):329-333. https://doi.org/10.1016/j.parkreldis.2010.02.007.

10. Huddleston DE, Langley J, Sedlacik J, et al. In vivo detection of lateral-ventral tier nigral degeneration in Parkinson's disease. Hum Brain Mapp. 2017;38(5):2627-2634. https:// doi.org/10.1002/hbm.23547.

11. Schapira $A H$, Obeso J. Timing of treatment initiation in Parkinson's disease: a need for reappraisal? Ann Neurol. 2006:59:559-562. https://doi.org/10.1002/ana.20789.

12. Aminoff MJ. Treatment should not be initiated too soon in Parkinson's disease. Ann Neurol. 2006;59:562-564. https:// doi.org/10.1002/ana.20814.

13. Hare DJ, Double KL. Iron and dopamine: a toxic couple. Brain. 2016;139(Pt4):1026-1035. https://doi.org/10.1093/ brain/aww022.

14. Dias V, Junn E, Mouradian MM. The role of oxidative stress in Parkinson's disease. J Parkinsons Dis. 2013;3(4):461-491. https://doi.org/10.3233/JPD-130230.

15. Olivieri S, Conti A, lannaccone $S$, et al. Ceruloplasmin oxidation, a feature of Parkinson's disease CSF, inhibits ferroxidase activity and promotes cellular iron retention. J Neurosci. 2011;31(50):18568-18577. https://doi.org/10.1523/ JNEUROSCI.3768-11.2011.

16. Wang J, Jiang $H$, Xie JX. Time dependent effects of 6-OHDA lesions on iron level and neuronal loss in rat nigrostriatal system. Neurochem Res. 2004;29(12):2239-2243. https:// doi.org/10.1007/s11064-004-7031-5.

17. Stockwell BR, Friedmann Angeli JP, Bayir H, et al. Ferroptosis: a regulated cell death nexus linking metabolism, redox biology, and disease. Cell. 2017;171(2):273-285. https:// doi.org/10.1016/j.cell.2017.09.021.

18. Castellani RJ, Siedlak SL, Perry G, Smith MA. Sequestration of iron by Lewy bodies in Parkinson's disease. Acta Neuropathol. 2000;100(2):111-114. https://doi.org/10.1007/ s004010050001.

19. Adamczyk A, Solecka J, Strosznajder JB. Expression of alpha-synuclein in different brain parts of adult and aged rats. J Physiol Pharmacol. 2005;56 (1):29-37.

20. Allen Reish HE, Standaert DG. Role of alpha-synuclein in inducing innate and adaptive immunity in Parkinson disease. J Parkinsons Dis. 2015;5(1):1-19. https://doi.org/10.3233/ JPD-140491.

21. Binolfi A, Rasia RM, Bertoncini CW, et al. Interaction of $\alpha$-synuclein with divalent metal ions reveals key differences: a link between structure, binding specificity and fibrillation enhancement. J Am Chem Soc. 2006;128(30):9893-9901. https://doi.org/10.1021/ja0618649.

22. Bharathi SS, Indi, Rao KSJ. Copper- and iron-induced differential fibril formation in $\alpha$-synuclein: TEM study.
Neuroscience Letters. 2007;424(2):78-82. https://doi.org/ 10.1016/j.neulet.2007.06.052.

23. Fujiwara $H$, Hasegawa $M$, Dohmae $N$, et al. $\alpha$-Synuclein is phosphorylated in synucleinopathy lesions. Nat Cell Biol. 2002;4(2):160-164. https://doi.org/10.1038/ncb748.

24. Liu LL, Franz KJ. Phosphorylation-dependent metal binding by $\alpha$-synuclein peptide fragments. J Biol Inorg Chem. 2007;12:234-247. https://doi.org/10.1007/s00775006-0181-y.

25. Santner A, Uversky VN. Metalloproteomics and metal toxicology of $\alpha$-synuclein. Metallomics. 2010;2(6):378-392. https://doi.org/10.1039/b926659c.

26. Friedlich AL, Tanzi RE, Rogers JT. The 5'-untranslated region of Parkinson's disease $\alpha$-synuclein messenger RNA contains a predicted iron responsive element. Mol Psychiatry. 2007;12(3):222-223. https://doi.org/10.1038/ sj.mp.4001937.

27. Li W., Jiang $H$, Song $N$, Xie J. Oxidative stress partially contributes to iron-induced $\alpha$-synuclein aggregation in SK-N-SH cells. Neurotox Res. 2011;19(3):435-442. https:// doi.org/10.1007/s12640-010-9187-x.

28. Febbraro F, Giorgi M, Caldarola $S$, et al. $\alpha$-Synuclein expression is modulated at the translational level by iron. NeuroReport. 2012;23(9):576-580. https://doi.org/10.1097/ WNR.0b013e328354a1f0.

29. Davies P, Moualla D, Brown DR. Alpha-synuclein is a cellular ferrireductase. PLoS One. 2011;6(1):e15814. https://doi. org/10.1371/journal.pone.0015814.

30. Yu S, Zuo X, Li Y, et al. Inhibition of tyrosine hydroxylase expression in alpha-synuclein-transfected dopaminergic neuronal cells. Neurosci Lett. 2004;367(1):34-39. https:// doi.org/10.1016/j.neulet.2004.05.118.

31. Logroscino G, Marder K, Graziano J, et al. Altered systemic iron metabolism in Parkinson's disease. Neurology. 1997;49(3):714-717. https://doi.org/10.1212/wnl.49. 3.714 .

32. Abbott RA, Cox M, Markus H, Tomkins A. Diet, body size and micronutrient status in Parkinson's disease. Eur J Clin Nutr. 1992;46(12):879-884.

33. Xu W, Zhi Y, Yuan Y, et al. Correlations between abnormal iron metabolism and non-motor symptoms in Parkinson's disease. J Neural Transm (Vienna). 2018;125(7):1027-1032. https://doi.org/10.1007/s00702-018-1889-X.

34. Si QQ, Yuan YS, Zhi Y, et al. Plasma transferrin level correlates with the tremor-dominant phenotype of Parkinson's disease. Neurosci Lett. 2018;684:42-46. https://doi. org/10.1016/j.neulet.2018.07.004.

35. Faucheux BA, Nillesse N, Damier $P$, et al. Expression of lactoferrin receptors is increased in the mesencephalon of patients with Parkinson disease. Proc Natl Acad Sci U S A. 1995;92(21):9603-9607. https://doi.org/10.1073/ pnas.92.21.9603.

36. Bonn D. Pumping iron in Parkinson's disease. Lancet. 1996;347(9015):1614. https://doi.org/10.1016/s0140-6736 (96)91094-6.

37. Aisen $P$, Leibman A. Lactoferrin and transferrin: a comparative study. Biochim Biophys Acta. 1972;257(2):314-323. https://doi.org/10.1016/0005-2795(72)90283-8. 
38. Leveugle B, Faucheux BA, Bouras C, et al. Cellular distribution of the iron-binding protein lactotransferrin in the mesencephalon of Parkinson's disease cases. Acta Neuropathol. 1996;91(6):566-572. https://doi.org/10.1007/ s004010050468.

39. Mochizuki $H$, Imai $H$, Endo $K$, et al. Iron accumulation in the substantia nigra of 1-methyl-4-phenyl-1,2,3,6-tetrahydropyridine (MPTP)-induced hemiparkinsonian monkeys. Neuroscience Letters. 1994;168(1-2):251-253. https://doi. org/10.1016/0304-3940(94)90462-6.

40. Fillebeen C, Dexter D, Mitchell V, et al. Lactoferrin is synthesized by mouse brain tissue and its expression is enhanced after MPTP treatment. Adv Exp Med Biol. 1998;443:293-300. https://doi.org/10.1007/978-1-4757-9068-9_36.

41. Fillebeen C, Mitchell V, Dexter D, et al. Lactoferrin is synthesized by mouse brain tissue and its expression is enhanced after MPTP treatment. Brain Res Mol Brain Res. 1999;72(2):183-194. https://doi.org/10.1016/s0169-328x (99)00221-1.

42. Grau AJ, Willig V, Fogel W, Werle E. Assessment of plasma lactoferrin in Parkinson's disease. Mov Disord. 2001;16(1):131-134. https://doi.org/10.1002/1531-8257 (200101)16:1<131::AID-MDS1008>3.0.C0;2-0

43. Zakharova ET, Sokolov AV, Pavlichenko NN, et al. Erythropoietin and Nrf2: key factors in the neuroprotection provided by apo-lactoferrin. Biometals. 2018;31(3):425-443. https:// doi.org/10.1007/s10534-018-0111-9.

44. Mohamed WA, Schaalan MF. Antidiabetic efficacy of lactoferrin in type 2 diabetic pediatrics; controlling impact on PPAR- $\gamma$, SIRT-1, and TLR4 downstream signaling pathway. Diabetol Metab Syndr. 2018;10:89. https://doi.org/10.1186/ s13098-018-0390-X.

45. Fillebeen C, Descamps L, Dehouck MP, et al. Receptormediated transcytosis of lactoferrin through the blood-brain barrier. J Biol Chem. 1999;274(11):7011-7017. https://doi. org/10.1074/jbc.274.11.7011.

46. Harada E, Araki Y, Furumura E, et al. Characteristic transfer of colostrum-derived biologically active substances into cerebrospinal fluid via blood in natural suckling neonatal pigs. J Vet Med A Physiol Pathol Clin Med. 2002;49(7):358-364. https://doi.org/10.1046/j.14390442.2002.00457.x.

47. Talukder MJ, Takeuchi T, Harada E. Receptor-mediated transport of lactoferrin into the cerebrospinal fluid via plasma in young calves. J Vet Med Sci. 2003;65(9):957-964. https://doi.org/10.1292/jvms.65.957.

48. Ji B, Maeda J, Higuchi M, et al. Pharmacokinetics and brain uptake of lactoferrin in rats. Life Sci. 2006;78(8):851-855. https://doi.org/10.1016/j.Ifs.2005.05.085.

49. Huang R, Ke W, Liu Y, et al. Gene therapy using lactoferrinmodified nanoparticles in a rotenone-induced chronic Parkinson model. J Neurol Sci. 2010;290(1-2):123-130. https:// doi.org/10.1016/j.jns.2009.09.032.

50. Hu K, Shi $Y$, Jiang $W$, et al. Lactoferrin conjugated PEG-PLGA nanoparticles for brain delivery: preparation, characterization and efficacy in Parkinson's disease. Int $J$ Pharm. 2011;415(1-2):273-83. https://doi.org/10.1016/ j.ijpharm.2011.05.062.
51. Bi C, Wang A, Chu $Y$, et al. Intranasal delivery of rotigotine to the brain with lactoferrin-modified PEG-PLGA nanoparticles for Parkinson's disease treatment. Int J Nanomedicine. 2016;11:6547-6559. https://doi.org/10.2147/IJN.S120939.

52. Yan $X, X u ~ L, B i ~ C$, et al. Lactoferrin-modified rotigotine nanoparticles for enhanced nose-to-brain delivery: LESA-MS/MS-based drug biodistribution, pharmacodynamics, and neuroprotective effects. Int J Nanomedicine. 2018;13:273-281. https://doi.org/10.2147/IJN.S151475.

53. Tang S, Wang A, Yan $X$, et al. Brain-targeted intranasal delivery of dopamine with borneol and lactoferrin co-modified nanoparticles for treating Parkinson's disease. Drug Deliv. 2019;26(1):700-707. https://doi.org/10.1080/10717544.20 19.1636420.

54. Takeuchi T, Hayashida Ki, Inagaki H, et al. Opioid mediated suppressive effect of milk-derived lactoferrin on distress induced by maternal separation in rat pups. Brain Res. 2003;979(1-2):216-224. https://doi.org/10.1016/s00068993(03)02941-x.

55. Kamemori N, Takeuchi T, Hayashida K, Harada E. Suppressive effects of milk-derived lactoferrin on psychological stress in adult rats. Brain Res. 2004;1029(1):34-40. https:// doi.org/10.1016/j.brainres.2004.09.015.

56. McManus B, Korpela R, O'Connor $\mathrm{P}$, et al. Compared to casein, bovine lactoferrin reduces plasma leptin and corticosterone and affects hypothalamic gene expression without altering weight gain or fat mass in high fat diet fed C57/BL6J mice. Nutrition \& Metabolism. 2015;12:53. https://doi. org/10.1186/s12986-015-0049-7.

57. Aleshina GM, Yankelevich IA, Zakharova ET, et al. Stressprotective effect of human lactoferrin. Ross Fiziol Zh Im I M Sechenova. 2016;102(7):846-851.

58. Pigeon C, Ilyin G, Courselaud B, et al. A new mouse liver specific gene, encoding a protein homologous to human antimicrobial peptide hepcidin, is overexpressed during iron overload. J Biol Chem. 2001;276:7811-7819. https://doi. org/10.1074/jbc.M008923200.

59. Nicolas G, Chauvet C, Viatte $L$, et al. The gene encoding the iron regulatory peptide hepcidin is regulated by anemia, hypoxia, and inflammation. J Clin Invest. 2002;110:10371044. https://doi.org/10.1172/JCl15686.

60. Urrutia P, Aguirre P, Esparza A, et al. Inflammation alters the expression of DMT1, FPN1 and hepcidin, and it causes iron accumulation in central nervous system cells. J Neurochem. 2013;126(4):541-549. https://doi.org/10.1111/jnc.12244.

61. Paesano R, Berlutti F, Pietropaoli M, et al. Lactoferrin efficacy versus ferrous sulfate in curing iron deficiency and iron deficiency anemia in pregnant women. Biometals. 2010;23(3):411-417. https://doi.org/10.1007/s10534-0109335-z.

62. Pulina MO, Sokolov AV, Zakharova ET, et al. Effect of lactoferrin on consequences of acute experimental hemorrhagic anemia in rats. Bull Exp Biol Med. 2010; 149:219-222. https://doi.org/10.1007/s10517-010-0911-6.

63. Cutone A, Frioni $A$, Berlutti $F$, et al. Lactoferrin prevents LPS-induced decrease of the iron exporter ferroportin in human monocytes/macrophages. Biometals. 2014;27(5):807-813. https://doi.org/10.1007/s10534-014-9742-7. 
64. De Domenico I, Ward DMcV, Bonaccorsi di Patti MC, et al. Ferroxidase activity is required for the stability of cell surface ferroportin in cells expressing GPI-ceruloplasmin. EMBO J. 2007;26:2823-2831. https://doi.org/10.1038/ sj.emboj.7601735.

65. Zakharova ET, Kostevich VA, Sokolov AV, Vasilyev VB. Human apo-lactoferrin as a physiological mimetic of hypoxia stabilizes hypoxia-inducible factor-1 alpha. Biometals. 2012;25(6):1247-1259. https://doi.org/10.1007/s10534012-9586-y.

66. Kostevich VA, Sokolov AV, Kozlov SO, et al. Functional link between ferroxidase activity of ceruloplasmin and protective effect of apo-lactoferrin: studying rats kept on a silver chloride diet. Biometals. 2016;29(4):691-704. https://doi. org/10.1007/s10534-016-9944-2.

67. Xue $Y Q$, Zhao LR, Guo WP, Duan WM. Intrastriatal administration of erythropoietin protects dopaminergic neurons and improves neurobehavioral outcome in a rat model of Parkinson's disease. Neuroscience. 2007;146(3):1245-1258. https://doi.org/10.1016/j.neuroscience.2007.02.004.

68. Rousseau E, Michel PP, Hirsch EC. The iron-binding protein lactoferrin protects vulnerable dopamine neurons from degeneration by preserving mitochondrial calcium homeostasis. Mol Pharmacol. 2013;84(6):888-898. https://doi. org/10.1124/mol.113.087965.

69. Xu SF, Zhang YH, Wang S, et al. Lactoferrin ameliorates dopaminergic neurodegeneration and motor deficits in
MPTP-treated mice. Redox Biol. 2019;21:101090. https:// doi.org/10.1016/j.redox.2018.101090.

70. Liu H, Wu H, Zhu N, et al. Lactoferrin protects against iron dysregulation, oxidative stress, and apoptosis in 1-methyl4-phenyl-1,2,3,6-tetrahydropyridine (MPTP)-induced Parkinson's disease in mice. J Neurochem. 2020;152(3):397415. https://doi.org/10.1111/jnc.14857.

71. Yu SY, Sun L, Liu Z, et al. Sleep disorders in Parkinson's disease: clinical features, iron metabolism and related mechanism. PLoS One. 2013;8(12):e82924. https://doi. org/10.1371/journal.pone.0082924.

72. Carro E, Bartolomй F, Bermejo-Pareja F, et al. Early diagnosis of mild cognitive impairment and Alzheimer's disease based on salivary lactoferrin. Alzheimers Dement (Amst). 2017;8:131138. https://doi.org/10.1016/j.dadm.2017.04.002.

73. Hamm-Alvarez SF, Janga SR, Edman MC, et al. Levels of oligomeric $\alpha$-Synuclein in reflex tears distinguish Parkinson's disease patients from healthy controls. Biomark Med. 2019;13(17): 1447-1457. https://doi.org/10.2217/bmm-2019-0315.

74. Bougea A, Koros C, Stefanis L. Salivary alpha-synuclein as a biomarker for Parkinson's disease: a systematic review. J Neural Transm (Vienna). 2019;126(11):1373-1382. https://doi.org/10.1007/s00702-019-02062-4.

75. Bougea A, Stefanis L, Paraskevas GP, et al. Plasma alphasynuclein levels in patients with Parkinson's disease: a systematic review and meta-analysis. Neurol Sci. 2019;40(5):929938. https://doi.org/10.1007/s10072-019-03738-1.
Alexey V. Sokolov - Doctor of Biological Sciences, Head of the Laboratory of Biochemical Genetics of the Department of Molecular Genetics, Institute of Experimental Medicine, Saint Petersburg, Russia; Professor of Chair of Fundamental Problems of Medicine and Medical Technology at Saint Petersburg State University, Saint Petersburg, Russia; Senior researcher of the Biochemical Research Department of the Preclinical Translational Research Centre, the Institute of Experimental Medicine of the Almazov Centre, Saint Petersburg, Russia. https://orcid.org/0000-0001-90330537. SPIN-code: 7427-7395. E-mail: biochemsokolov@ gmail.com.

Irina $V$. Miliukhina - $\mathrm{PhD}, \mathrm{MD}$, Head of the Center of the Neurodegenerative Disorders, Institute of Experimental Medicine, Saint Petersburg, Russia. http://orcid.org/ 0000-0002-6433-542X. SPIN-code: 1767-2266. E-mail: milyukhinaiv@yandex.ru.

Yury P. Belsky - Doctor of Medical Sciences, Head of the Biochemical Research Department of the Preclinical Translational Research Centre, the Institute of Experimental Medicine of the Almazov Centre, Saint Petersburg, Russia. E-mail: belsky59@mail.ru.
Алексей Викторович Соколов - д-р биол. наук, заведующий лабораторией биохимической генетики отдела молекулярной генетики, ФГБНУ «Институт экспериментальной медицины», Санкт-Петербург; профессор кафедры фундаментальных проблем медицины и медицинских технологий ФГБОУ ВПО «СанктПетербургский государственный университет», СанктПетербург; старший научный сотрудник Научноисследовательского отдела Центра доклинических и трансляционных исследований Института экспериментальной медицины ФГБУ «НМИЦ им. В.А. Алмазова» Минздрава России, Санкт-Петербург. https:// orcid.org/0000-0001-9033-0537. SPIN-код: 7427-7395. E-mail: biochemsokolov@gmail.com.

Ирина Валентиновна Милюхина - канд. мед. наук, руководитель научно-клинического центра нейродегенеративных заболеваний, старший научный сотрудник, ФГБНУ «Институт экспериментальной медицины», Санкт-Петербург. http://orcid.org/0000-0002-6433-542X. SPIN-код: 1767-2266. E-mail: milyukhinaiv@yandex.ru.

Юрий Павлович Бельский - д-р мед. наук, руководитель Научно-исследовательского отдела Центра доклинических и трансляционных исследований Института экспериментальной медицины ФГБУ «НМИЦ им. В.А. Алмазова» Минздрава России, Санкт-Петербург. E-mail: belsky59@mail.ru. 
Nataly V. Belska - Doctor of Medical Sciences, Leading Researcher of the Toxicology Research Department of the Preclinical Translational Research Centre, the Institute of Experimental Medicine of the Almazov Centre, Saint Petersburg, Russia. E-mail: natalybelska@yandex.ru.

Vadim B. Vasilyev - Doctor of Medical Sciences, Head of the Department of Molecular Genetics, Institute of Experimental Medicine, Saint Petersburg, Russia; Professor of Chair of Fundamental Problems of Medicine and Medical Technology at Saint Petersburg State University, Saint Petersburg, Russia. https://orcid.org/0000-0002-9707262X. SPIN-code: 6699-6350. E-mail: vadim@biokemis.ru.

Corresponding author / Контактное мицо
Наталия Витальевна Бельская - д-р мед. наук, ведущий научный сотрудник Научно-исследовательского отдела токсикологии Центра доклинических и трансляционных исследований Института экспериментальной медицины ФГБУ «НМИЦ им. В.А. Алмазова» Минздрава России, Санкт-Петербург. E-mail: natalybelska@ yandex.ru.

Вадим Борисович Васильев - д-р мед. наук, руководитель отдела молекулярной генетики, ФГБНУ «Институт экспериментальной медицины», Санкт-Петербург; профессор кафедры фундаментальных проблем медицины и медицинских технологий ФГБОУ ВПО «СанктПетербургский государственный университет», СанктПетербург. https://orcid.org/0000-0002-9707-262X. SPINкод: 6699-6350. E-mail: vadim@biokemis.ru.

Alexey V. Sokolov / Алексей Викторович Соколов

E-mail: biochemsokolov@gmail.com 